antennæ are more clearly bicolorous apically. Præscutal stripes orange instead of dark brown, the median pair narrow, widely divided by the ground-colour. Wings strongly tinged with yellow before the cord, the costal cells yellow instead of brown. Abdomen more yellowish, especially laterally. Male hypopygium with the median area of the eighth sternite with two broadly triangular teeth, the notch between them V-shaped or narrowly U-shaped. The female is similar to the male but somewhat smaller.

Habitat.-Central United States.

Holotype.-- $\sigma^{7}$, Lawrence, Douglas Co., Kansas, June 6, 1918. Allotype.-o, with the type (M. M. Alexander).

Paratopotypes.- Several or 9 .

I have examined the type of umbrosa at Cambridge, and have seen paratypes of inermis, and they both refer to the smaller darkcoloured species of this group. It is possible that still other species remain to be separated from this complex.

\title{
SOME NEW OR SCARCE COLEOPTERA FROM WESTERN AND SOUTHERN FLORIDA.
}

\author{
BY W. S. BLATCHLEY, INDIANAPOLIS, INDIANA.
}

Between December 1, 1917, and April 1, 1918, the writer was in Florida and collected Coleoptera and Orthoptera for much of the time. The most of the collecting was done about Dunedin, ${ }^{*}$ a town in Pinellas County on the west coast, but in tate February and early March a trip was taken to the Lake Okeechobee region, during which several days' collecting was done at each of the following places: Lakeland, Ft. Myers, LaBelle, Moore Haven** and Okeechobee City. One day was also spent on the east shore of Lake Okeechobee at the point where the Palm Beach Canal leaves the lake. The species of Coleoptera herein noted, on account of their apparent scarcity in the State, or which are regarded as undescribed forms, were for the most part taken during the winter at some one or more of the places above mentioned.

* See Canadian Entomologist, 1917, 137.

* This is a new town on the west side of Lake Okeechobee, at the point where the Caloosahatchie River formerly emerged from the lake. A large area of the old lake area southeast of the town has been drained and is now under cultivation.

December, 1918 
Loxandrus brunneus, sp. nov.-Elongate-oval. Above nearly uniform dark reddish brown, strongly shining; head and last ventral segment often piceous brown. Under surface pale chestnut brown; legs, mouth-parts and three basal joints of antennæ brownish yellow, outer pubescent joints of antennæ darker. Head longer than broad, eyes prominent. Thorax slightly wider than long, sides broadly and evenly curved from base to apex; front and hind angles slightly obtusely angulate; disk smooth, its sides in front of middle declivent; median and apical impressed lines fine, entire; basal impressions linear, deep. Elytra iridescent, two and one-fourth times as long as thorax, one-fifth wider at base; sides subparallel from behind humeri to apical third, then rounded and converging to apex; striæ rather deep, their inner margin very finely crenate-punctate; intervals smooth, feebly convex, the third with the usual dorsal puncture of the genus. Length $6.3-6.8 \mathrm{~mm}$.

This species differs from all others of its approximate size except crenatus in its usually uniform shining brown colour. This is not due to immaturity, as numerous specimens, all of the same hue, have been taken. It was frequent beneath the wash-up on the shore of Lake Okeechobee, four miles southeast of Moore Haven, March 1-3, and when uncovered ran very swiftly to the nearest shelter. It was also taken at LaBelle and has been in the writer's collection undetermined since 1911, when specimens were secured about the margins of ponds and bay-heads at Sarasota. Specimens sent to the late Frederick Blanchard were returned as unknown to him, and H. P. Loding, of Mobile, Alabama, who has a large collection of southern forms of the genus, says he has nothing like it.

Loxandrus saphyrinus Chaud.--Leng, in his "Carabidæ of Florida,"* seems to doubt both the validity of this species and its occurrence in Florida. A specimen taken at Sanford, March 28, runs only to saphyrinus by Le. Conte's tables, and is very distinct from reflexus Lec. of which Leng considers it a synonym, being slightly larger, with thorax less transverse, its sides more rounded, elytral striæ more coarsely punctate and surface with iridescence much stronger, being more brilliant than in any species of the genus known to me. Chaudoir's type of saphyrinus was from ${ }^{*}$ Bull. Am. Mus., Nat. Hist., XX়XIV, 1915, 579. 
Louisiana, and there is, therefore, no reason why it should not occur in Florida.

Loxandrus flavilimbus, sp. nov.--Elongate-oval.' Above dark reddish or chestnut brown, strongly shining, the side margins and hind angles of thorax, and the basal three-fourths of side margins of elytra dull red; mouth-parts, legs and under surface pale reddish brown; apical two-thirds of antennæ fuscous. Head as broad as long; eyes large, feebly convex. Thorax subquadrate, disk smooth, sides broadly but evidently curved, front angles obtuse, hind ones broadly rounded into base; median line very faint, basal impressions shallow, shorter than usual. Elytra as wide at base as thorax, slightly more than twice as long; humeri feebly curved, sides behind them almost straight for three-fourths their length, then rounded and sinuate to apex; strix shallow, their punctures rather coarse, close-set, faint or subobsolete on apical third; intervals smooth, very feebly convex. Length $10 \mathrm{~mm}$.

Beneath board near border of pond north of Dunedin; Jan. 1, rare. Loding (Ms.) says he has an unnamed specimen which he considers identical. The size, pale legs, pale margin of thorax and elytra and coarsely punctured strix preclude it from being any of the species treated in LeConte's tables. Two or three other species or forms of Loxandrus are at hand which cannot be placed by his tables. The genus, as represented in Florida, is one of the largest of the Carabidæ, but is badly in need of revision.

Lebia abdominalis Chaud.-This is recorded only from Enterprise and the Biscayne Bay region. A half dozen were found beneath the debris on the shore of Lake Okeechobee, near Moore Haven, and one was beaten from oak at Lakeland.

Lebia furcata Lec.-A single specimen, the first I have taken in Florida, was beaten Dec. 17 from the dead leaves of a cabbage palmetto near Dunedin. It is listed as rare at Tampa, Crescent City and Gainesville.

Plochionus amandus Newm.-A male, typically coloured, as described by Horn, ${ }^{*}$ was beaten from a mass of Spanish moss on the margin of Skinner's Hammock, north of Dunedin, Feb. 11. From the descriptions I judge that amandus is only a colour form

*Trans. Am. Ent. Soc., X, 1882, 146. 
of discoideus Schaupp. $\dagger$ Horn (loc. cit.) records one specimen from Florida.

Onota floridana Horn.-One specimen was beaten from oak at La Belle on Feb. 26. It is a scarce Floridian species, hitherto recorded from Lake Poinsett, Haw Creek, Enterprise and Biscayne Bay.

Selenophorus chokoloskei Leng.--I find two specimens of this new form among my series of $S$. palliatus. They are labeled Dunedin, March 25, 1915. It was described from Chokoloskee and Everglade.

Selenophorus depressulus Casey.-This is undoubtedly distinct from S. iripennis Say, and seems to be more common in southern Florida than the latter, the specimens at hand being from Sanford, Lake Istokpoga, Ft. Myers and Dunedin, the dates ranging between Dec. 30 and March 26. It occurs beneath cover, usually in rather dry spots, about the borders of gardens and cultivated fields. From iripennis it may be easily separated by its wider thorax which is less narrowed basally, its hind angles broadly rounded instead of obtuse and basal depressions more finely and densely punctate. Both species have the dorsal series of punctures, characteristic of the genus, very small and they are, therefore, apt to be confused with species of Stenolophus.

Stenolophus carbonarius Dej.-A single specimen was taken from beneath the beach debris southeast of Moore Haven on March 1. It differs from Indiana examples only in having the sutural striæ one-third shorter. Not before recorded from Florida, though LeConte* gives the range as "Middle and Southern States."

Olla oculata sobrina Casey.-This form was described from Florida without definite locality. Schwarz (Ms.) ${ }^{* *}$ has noted it from Jacksonville. Specimens at hand are from that place, Gainesville, Sanford, Dunedin and Ft. Myers, all taken between Feb. 24 and April 24. About Dunedin it apparently hibernates

†Bull. Brk. Ent. Soc., II, 1886, 86.

${ }^{*}$ Bull. Brook. Ent. Soc., VI, 1883, 14.

**The Schwarz (Ms.), referred to frequently in this paper, is an annotated copy of his "Coleoptera of Florida," in which all additional species of Florida Coleoptera taken by himself and others, up to within the last few years, are carefully recorded, with localities, dates, etc. Through the kindness of Mr. Schwarz I was able to borrow this annotated list from the Smithsonian Library and made a copy of all the manuscript additions and records. 
in bunches of Spanish moss, but has been taken also from oak and plum trees.

Psyllobora parvinotata Casey.--Several specimens taken by beating on Hog Island. A submaritime species known from Haulover, Palm Beach and Key West. Distinguished by its lack of antescutellar spot of pronotum and small, isolated, drab spots of elytra, the general colour also paler than in 20-maculata. Leng regards it as only a varicty.

Psyllobora pallidicola Blatch.--This small Coccinellid was described* as a variety of $P$. 20-maculata, but further study of its habits and characters led me to believe it a valid species. It is always smaller, non-alutaceous and wholly without spots on thorax. As. P. N. Timberlake, Entomologist of the Hawaiian Sugar Planters' Experiment Station at Honolulu, was studying the male genitalia of Coccinellidæ, I sent him specimens of pallidicola for examination. Under date of Dec. 7, 1917, he wrote: "At your request I have compared the male genitalia of your Psyllobora pallidicola with 20-maculata and have found considerable differences, the principal one of which resides in the length of the adeagus. In pallidicola the xdeagus is very short compared with 20-maculata, in which species it is drawn out like a whiplash. $P$. tadata Lec. and borealis Casey, are similar if not identical with 20-maculata in this respect, and I doubt whether they are anything more than geographical variants. $P$. pallidicola, however, is undoubtedly distinct."

About Dunedin $P$. pallidicola occurs frequently throughout the winter on oak and wax myrtle, but is never taken with 20maculata which is there a scarce species. The former has also been taken at Lakeland, Ft. Myers and La Belle, and is probably widely distributed throughout central and southern Florida, and north at least as far as Ormond.

Hyperaspis nigrosuturalis, sp. nov.-Broadly oval or subhemispherical, convex. Black, shining; front of head, apical angles and side margins of thorax to behind middle, yellow. Elytra red, their basal sixth, a very narrow margin and wider sutural stripe, black; the sides of the red disk connected just behind the scutellum, the sutural stripe being incomplete. Sides of ventral

${ }^{*}$ Can. Ent., 1914, 66. 
segments tinged with reddish. Tarsi brownish fuscous. Upper surface distinctly and rather coarsely punctuate, the punctures separated by more than their own diameters; under surface more coarsely and shallowly punctate. Length $3 \mathrm{~mm}$.

One specimen beaten from bunch of Spanish moss near the margin of a lake north of Lakeland, Feb. 22. Differs in colour from any described form. Closely related to $H$. tredata Lec. and regalis Casey.

Scymnus bigemmeus Horn,--Taken on Hog Island Jan. 20 and Feb. 9 by beating vegetation just back of the skirting fringe of mangrove, Rhizophora mangle L. Described in 1895 from Punta Gorda and Biscayne Bay, and since recorded only from Miami.

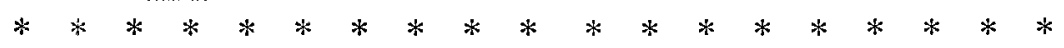

Near the top of page 445 of Schwarz's "Coleoptera of Florida"* is the following: "Anamorphus pusillus Zimm. ms. E. rare with the preceding." The preceding referred to is Rhymbus ulkei $\mathrm{Cr}$., which. Schwarz mentions as "E. (Enterprise) rare, lives on fungus which grows on dead branches." At the bottom of the page is a footnote by Le Conte as follows: "I have not described this genus (Anamorphus), as its affinities are not yet clearly made out. It is a small, rounded, testaceous, hairy insect having somewhat the aspect of Rhymbus but without prothoracic lines; the tarsi are not dilated. The specimens at my disposal are not sufficient for a thorough investigation." It will be noted that he does not refer to the specific name pusillus, but only to the genus Anamorphus.

In $1883^{* *}$ Le Conte \& Horn diagnosed, and, therefore, first validated, the genus Anamorphus as follows: "Body hemispherical; tarsi narrow, 4-jointed; prothorax with large, finely margined, basal lobe, and a basal line each side, running forwards and then curving inwards; antennæe 9-jointed, club elongate, very loose."

Henshaw in his Check List (1885, p. 49) mentions Anamorphus Lec., but accredits no species whatever to it. In 1906 Dury $\dagger$ recorded Anamorphus pusillus Zimm. as occurring near Cincinnati,

*Proc. Amer. Phil. Soc., XVII, 1878.

**Classification Col. N. Amer., 120.

†Journ. Cinc. Soc. Nat. Hist., XX, 251. 
O., and in $1910^{* *}$ the writer in a key gave a brief diagnosis of the genus, based on that of Le Conte and Horn, and added: "Anamorphus pusillus Zimm, pale reddish brown, length $1.5 \mathrm{~mm}$., has been taken by Dury near Cincinnati."

The above constitute all references which can be found in the literature available to either the genus Anamorphus or the species pusillus. Whether pusillus was sufficiently characterized, when it was assigned to a genus not then defined, and therefore invalid, and the species itself described only as a "small, rounded testaceous hairy insect, etc.," as set forth above, I leave for better nomenciatorial cranks than myself to settle.

A careful comparison shows that the specimen in the Dury collection differs sufficiently from two at hand from Florida to justify a new name, and as pusillus is known only from the description quoted, I give the principal characters of each as follows:

Anamorphus pusillus Lec.-Rounded-oval or semi-hemispherical, strongly convex. Dark reddish or chestnut brown, shining, rather thickly clothed with long, semi-erect, yellow hairs; legs and antennæ dull yellow. Eyes small, coarsely facetted, widely separated. Thorax twice as wide as long at middle, sides feebly curved, hind angles rectangular, disk minutely and sparsely punctate, each puncture bearing a very slender, yellow hair; basal lobe prominent, triangular, its apex rounded, the curved basal lines very fine: Elytra one-fifth wider than thorax, their common base widely and rather deeply emarginate to receive the basal thoracic lobe; umbones prominent; sides strongly declivent; disk with numerous scattered punctures, much coarser and more distinct than those of thorax, each bearing a longer, coarser, more erect yellow hair. Under surface smooth, polished. Length $1.2 \mathrm{~mm}$.

Dunedin, Fla., March 27, 1916; March 23, 1918. Both were taken while beating in Skinner's Hammock, one mile nor theast of Dunedin. One of the two has the head and apical third of elytra darker than the general hue. It is probably frequent in wet hammocks throughout the greater portion of Florida, but over-

**Coleoptera of Ind., 535 . 
looked on account of the small size. Schwarz (Ms.) lists it also from Crescent City, Fla.

Anamorphus waltoni, sp. nov.-Larger and broader than pusillus, the shape hemispherical rather than oval. Colour uniform pale reddish brown. Elytral punctures much finer and more dense than in pusillus, the pubescence therefore thicker and more evident. Characters otherwise much the same as those of pusillus. Length $1.6 \mathrm{~mm}$.

Named in honour of L. B. Walton of Gambier, Ohio, the recognized American authority on the Endomychidae.

Dury's record, cited above, is as follows: "One specimen July 7 , taken feeding on beech $\log$ in company with Rhymbus minor, which species it resembles in an astonishing manner."

Nausibius repandus Lec.- - Listed by Schwarz as very rare under oak bark at Tampa. A single specimen was taken at Dunedin while sweeping huckleberry and other low shrubs on Jan. 29. It is a southern form, described from the District of Columbia, and appears to be everywhere very scarce.

Ino reclusa Lec.-A single specimen was beaten March 26 from the dead limbs of the Florida button-bush, a shrub resembling the black mangrove and growing just back of the borders of the latter near the middle of Hog Island. The beetle was described from Columbus, Texas, and has not before been recorded from Florida. It is one of the smallest $(2 \mathrm{~mm}$.) of Cucujids, pale brown with broad head, thorax triangular, wide in front, very narrow at base, and elytra covering only half of the abdomen.

Catogenus rufus Fab.-This widely distributed species has been recorded from several stations in Florida, though only six examples have been taken by me during seven winters' collecting. It is mentioned here only to make known its power of resisting cyanide fumes. On December 15 three were found beneath the bark of a pine log and placed with other specimens in a heavily charged cyanide bottle. Five hours later they were all alive and active, though everything else in the bottle had long before "passed on." I replaced them in the bottle and left them for 24 hours, when they, too, appeared to have succumbed. They were then put in a pill box with proper label and date, and I was much sur- 
prised on opening this ten days later to find two of them alive and kicking. They were for a second time "gassed" for 24 hours, and then put back with their dead companions. Some two or three weeks later I found one of them was still in "status ante bellum," so I gave him a week's cyanide treatment, and he never "came to" thereafter. The bottle was in almost daily use until April 1, and killed quickly all other insects placed in it up to that date.

\section{RECENT CANADIAN PUBLICATIONS. \\ (Continu ad from Page 392)}

Proceedings of the Entomological Society of British Columbia.-March, 1916. No. 8. Systematic Series. Victoria, 1918. 30 pp., 3 pls.

This report contains the following papers and addresses:-

Presidential Address: G. O. Day. Pp. 4-6.

On the species of the genus Pero occurring in British Columbia: E. H. Blackmore. Pp. 7-9 Contains remarks on the genus and descriptions of the four species known from British Columbia, with notes on their distribution.

The occurrence of Glutops singularis Burgess in British Culumbia: R. C. Treherne. P. 10. Records the capture of this rare but widely distributed fly at Agassiz, B. C.

An Appreciation: A. F. Winn. Pp. 11-13. Conveys greetings from the Parent Society, with words of appreciation of the work of the B. C. Branch, and a plea for co-operation among the various branches of the Society.

Furthur additions to the list of British Columbia Geometrido: E. H. Blackmore. Pp. 14-20. An annotated list of 23 species and varieties recorded for the first time from British Columbia, with synonymic notes on some of the forms. Ten species are illustrated from photographs.

Larva Rearing: G. O. Day. Pp. 21-27. Describes methods of collecting and rearing Lepidopterous larvæ; largely quoted from an article by E. Rippon, in the Entomologist, 1915.

In Memoriam. Captain R. V. Hardy: R. S. Sherman. Pp. 29 30, with portrait.

December, 1918 